\title{
ABT-737 accelerates butyrate-induced death of HL-60 cells. Involvement of mitochondrial apoptosis pathway
}

\author{
Andrea Štefaniková, Katarína Kliková, Jozef Hatok and Peter Račay \\ Department of Medical Biochemistry, Jessenius Faculty of Medicine, Comenius University, Martin, Slovak Republic
}

\begin{abstract}
The aim of presented study was to determine effect of NaBu in combination with ABT-737 on cell survival of leukemic cell line HL-60. In addition, analysis of molecular mechanism of $\mathrm{NaBu}$ action with a focus on mitochondrial apoptosis was performed. Both NaBu and ABT-737 are inducing death of HL-60 cells with different kinetics. ABT-737-induced cell death is fast while NaBu-induced death preceded by cell cycle arrest in G2 phase is rather slow. Cell viability was significantly decreased after 48 hours of incubation with 2 and $5 \mathrm{mmol} / \mathrm{l}$ of $\mathrm{NaBu}$ while it was significantly decreased after 24 hours of incubation with $1 \mu \mathrm{mol} / \mathrm{l}$ of ABT-737 combined with 2 and $5 \mathrm{mmol} / \mathrm{l}$ of $\mathrm{NaBu}$. Incubation of HL-60 cells with $\mathrm{NaBu}$ was associated with increased level of pro-apoptotic protein $\mathrm{BIM}_{\mathrm{EL}}$ and decreased levels of anti-apoptotic proteins of Bcl-2 family as well as GRP78 involved in ER stress signalling. It seems that ABT-737 accelerates NaBu-induced death of HL-60 cells due to mitochondrial apoptosis resulting from ABT-737-mediated inhibition of functions and NaBu-induced decrease of the levels of anti-apoptotic Bcl-2 family proteins as well as due to accelerated decrease of GRP78 observed after the treatment of cells with combination of $\mathrm{NaBu}$ and ABT-737. The effect of combination of both drugs on survival of HL-60 cells seems to be synergistic at high concentrations of $\mathrm{NaBu}(2$ and $5 \mathrm{mmol} /$ ) while it is rather antagonistic at concentrations of $\mathrm{NaBu}$ less than $1 \mathrm{mmol} / \mathrm{l}$. Finally, it might be assumed that $\mathrm{NaBu}$ is capable to induce cell death with mechanisms independent from mitochondrial apoptosis.
\end{abstract}

Key words: HL-60 - Sodium butyrate - ABT-737 - Bcl-2 family proteins - GRP78

\section{Introduction}

Butyrate that is naturally produced in the human colon by the bacterial fermentation of dietary fibres is a non-toxic shortchain fatty acid with a broad physiologic impact (Fauser et al. 2011). Besides its ability to serve as an energetic substrate for some cells, it can inhibit cell growth, by cell cycle arrest either in G1 or G2 phase, and promote differentiation in several normal and tumour cells (Pajak et al. 2007). These effects were explained by evidence that butyrate acts as an inhibitor of histone deacetylases class I and IIa (Bolden et al. 2006; Carew et al. 2008), thereby inducing histone hyperacetylation, chromatin relaxation and changes in the expression of several different regulatory proteins (Carew et al. 2008; Marks 2010). In particular, it has been documented

Correspondence to: Peter Račay, Department of Medical Biochemistry, Jessenius Faculty of Medicine, Comenius University, Mala Hora 4, 03601 Martin, Slovak Republic

E-mail: racay@jfmed.uniba.sk that butyrate can induce cell-cycle arrest by increasing the expression of $\mathrm{p} 21^{\text {WAF/CIP1 }}$ (Rosato et al. 2002) and p27 Kip1 (Litvak et al. 1998). In addition, butyrate-dependent induction of retinoblastoma $(\mathrm{Rb})$ protein hypophosphorylation was included as p21-independent mechanism of butyrateinduced cell cycle arrest in G1 phase (Vaziri et al. 1998). Apart from the effects on the cell cycle and differentiation, butyrate can also induce cell death in many cancer cell lines (Pajak et al. 2007), including leukaemic HL-60 cells (Calabresse et al. 1993; Filippovich et al. 1994; Zimra et al. 1997; Rosato et al. 2003). It has been suggested that a cell death effect of butyrate related to the initiation of p53-independent mitochondrial apoptosis correlates with down-regulation of anti-apoptotic proteins of Bcl-2 family and up-regulation of pro-apoptotic proteins of Bcl-2 family (Bolden et al. 2006; Carew et al. 2008; Marks 2010) as well as activation of caspase 9 and caspase 3 (Shao et al. 2004; Vrba et al. 2010). In addition to mitochondrial apoptosis, butyrate can induce another types of cell death namely autophagy (Shao et al. 2004; Tang et al. 2011). 
ABT-737 is a synthetic small BH3-only mimetic molecule that has the capacity to bind to the hydrophobic clefts of $\mathrm{Bcl}-2, \mathrm{Bcl}-\mathrm{X}_{\mathrm{L}}$, and Bcl-w (Oltersdorf et al. 2005). Binding of ABT-737 to Bcl-2, Bcl- $\mathrm{X}_{\mathrm{L}}$, and Bcl-w disrupts their antiapoptotic functions and is associated with death of various tumour cells whereas normal cells exhibit minimal sensitivity to ABT-737 (Chauhan et al. 2007). With respect to leukaemia, ABT-737 effectively kills leukaemic blasts, progenitor and stem cells without affecting normal hematopoietic cells (Konopleva et al. 2006). Since ABT-737 effectively binds to the $\mathrm{Bcl}-2$ and $\mathrm{Bcl}-\mathrm{X}_{\mathrm{L}}$ but exhibits minimal affinity to $\mathrm{Mcl}-1$ (Oltersdorf et al. 2005), sensitivity of tumour cells to ABT737 is significantly determined by the relative expression levels of Bcl-2/ Bcl- $\mathrm{X}_{\mathrm{L}}$ versus $\mathrm{Mcl}-1$ (Konopleva et al. 2006; van Delft et al. 2006). In hand with this, down-regulation of Mcl-1 expression dramatically enhances ABT-737 cytotoxicity (Chen et al. 2007; Lin et al. 2007). On the other hand, ABT-737 displaces BIM from the BH3-binding pocket of $\mathrm{Bcl}-2$ that is associated with BIM-mediated activation of Bax and consequent initiation of mitochondrial apoptosis (Del Gazo Moore et al. 2007). It seems that the extent of Bcl-2 bound to $\mathrm{Bim}$, rather than total $\mathrm{Bcl}-2$ expression levels, may determine cellular sensitivity to ABT-737 (Deng et al. 2007). In hand with this, ABT-737 has been shown to interact with certain anticancer agents capable of up-regulating BIM, (Kuroda et al. 2006; Zhang et al. 2008) including histone deacetylase inhibitors (HDACi) (Chen et al. 2009). However, ABT-737 could synergize with HDACi in vitro to kill lymphoma cells over-expressing Bcl-2 and Bcl- $\mathrm{X}_{\mathrm{L}}$ (Whitecross et al. 2009). In addition to mitochondrial apoptosis initiation, it seems that ABT-737 may exhibit additional cellular activities like induction of cell-cycle arrest and consequent senescence (Song et al. 2011) or multiple pathways culminating in autophagy (Malik et al. 2011).

The aim of presented study was to determine effect of sodium butyrate $(\mathrm{NaBu})$ in combination with ABT-737 on survival of leukaemic cell line HL- 60 with a focus on kinetics of cellular action of both drugs. In addition, analysis of $\mathrm{NaBu}$ impact on the level of selected proteins of Bcl-2 family was performed in time- and concentration-dependent manner.

\section{Materials and Methods}

Sodium butyrate, propiodium iodide, (3-(4,5-dimethylthiazol-2-yl)-2,5-diphenyltetrazolium bromide (MTT), sodium dodecylsulphate (SDS) (all from Sigma Aldrich), ABT-737 (Abbott Laboratories). Rabbit polyclonal antibodies raised against Bax (Santa Cruz Biotechnology, SC-439), Bcl- $\mathrm{X}_{\mathrm{L}}$ (Santa Cruz Biotechnology, SC-7195), BIM (Santa Cruz Biotechnology, SC-11425), $\gamma$-H2AX (Santa Cruz Biotechnology, SC-101696) and Mcl-1 (Santa Cruz Biotechnology, SC-20679). Mouse monoclonal antibodies raised against
Bcl-2 (Santa Cruz Biotechnology, SC-7382), LC3 $\beta$ (Santa Cruz Biotechnology, SC-271625) and $\beta$-actin (Santa Cruz Biotechnology, SC-47778). Goat polyclonal antibody raised against GRP78 (Santa Cruz Biotechnology, SC-1051). Mouse anti-goat (SC-2354), mouse anti-rabbit (SC-2357) and goat anti-mouse (SC-2005) secondary antibodies conjugated with horse radish peroxidase.

\section{Cell culture}

HL-60 cells (ATCC) were routinely maintained in IMDM medium supplemented with $20 \%$ fetal bovine serum, $1 \%$ penicillin-streptomycin (all PAA) at an optimal cell density of $0.5 \times 10^{6}$ cells $/ \mathrm{ml}$ at $37^{\circ} \mathrm{C}$ and $5 \% \mathrm{CO}_{2}$ humidified atmosphere. The medium was changed every 3 days.

\section{Cell viability assay}

HL-60 cells were incubated 24-72 h with or without various concentrations of $\mathrm{NaBu}$ and/or ABT-737. Cells were seeded in 96 -well plates at a concentration of $0.5 \times 10^{6} \mathrm{per} \mathrm{ml}$. At the end of incubation the absorbance of formazan, which results from oxidation of added MTT by vital cells, was determined spectrophotometrically using microplate reader BioRad 2010. The relative viability of the cells was determined as ratio of optical density of formazan produced by treated cells to optical density of formazan produced by non-treated control cells and expressed as percent of control. The cell growth was determined as time course of optical density of formazan produced by particular cell population.

\section{Cell cycle analysis}

After treatment of HL-60 cells with 1, 2 and $5 \mathrm{mmol} / \mathrm{l} \mathrm{NaBu}$ and/or $1 \mu \mathrm{mol} / 1 \mathrm{ABT}-737$ for $24-72 \mathrm{~h}$, the cells $\left(1 \times 10^{6}\right)$ were fixed in $70 \%$ ethanol for 1 hour at $4^{\circ} \mathrm{C}$ and washed in PBS with $2 \% \mathrm{FBS}$ and $0.01 \% \mathrm{NaN}_{3}$. The cells were incubated with $75 \mu \mathrm{l} \mathrm{mg} / \mathrm{ml} \mathrm{RNase}$ A for $30 \mathrm{~min}$ at $37^{\circ} \mathrm{C}$, then $20 \mu \mathrm{g} / \mathrm{ml}$ of propidium iodide was added and incubated $30 \mathrm{~min}$ at RT in the dark. Cells were analyzed using MACSQuant flow cytometer (Miltenyi Biotec).

\section{Western blotting}

Isolation of proteins was performed by extraction with TriReagent (Invitrogen) according to manufacturer's instructions. Extracted proteins were separated on 12\% SDS-polyacrylamide gels under reducing conditions with $30 \mu \mathrm{g}$ of protein loaded per lane, transferred to nitrocellulose membrane via semidry transfer and probed with antibodies specific to $\mathrm{Bcl}-\mathrm{X}_{\mathrm{L}}, \mathrm{Bcl}-2$, Bax, BIM, Mcl-1, GRP78, LC3 $\beta, \gamma-\mathrm{H} 2 \mathrm{AX}$ and $\beta$-actin (Santa Cruz Biotechnology). After incubation of membranes with particular secondary antibodies, im- 
munopositive bands were visualized using the chemiluminiscent substrate SuperSignal West Pico (Thermo Scientific) and Chemidoc XRS system (BioRad). Specific bands were documented by Quantity One software (BioRad).

\section{Combined drug effect analysis}

The combination effect and potential synergy were evaluated from quantitative analysis of dose-effect relationships, as described (Abrams et al. 2010) and a combination index was calculated using the CalcuSyn software (Biosoft, Cambridge, UK). This method of analysis generally defines CI values of 0.9 to 1.1 as additive, 0.3 to 0.9 as synergistic, and $<0.3$ as strongly synergistic, whereas values $>1.1$ are considered antagonistic.

\section{Statistical analysis}

All statistical analyses were done using GraphPad InStat V2.04a (GraphPad Software). The unpaired Tukey's test was used to determine differences between viability of control and treated cells. Significance level was set at $p<0.05$.

\section{Results}

Incubation of HL-60 cells with different concentrations of $\mathrm{NaBu}$ for 24, 48 and 72 hours has revealed time- and concentration-dependent impact of $\mathrm{NaBu}$ on relative viability of HL-60 cells (Fig. 1A). NaBu in concentrations 2 and $5 \mathrm{mmol} / \mathrm{l}$ led to the significant decrease of relative viability of HL-60 cells which was dominant after 48 hours of incubation. The estimated lethal concentrations of $\mathrm{NaBu}$ leading effectively to decrease of HL-60 cell population to $50 \%$ of control $\left(\mathrm{LC}_{50}\right)$ were $1.75 \pm 0.18$ and $1.25 \pm 0.14$ $\mathrm{mmol} / \mathrm{l}$ after 48 and 72 hours, respectively. On the other hand, the impact of ABT-737 on viability of HL-60 cells is faster and significant decrease of relative cell viability was already observed after 24 hours of incubation (Fig. 1B) at concentrations of ABT-737 more than $1 \mu \mathrm{mol} / \mathrm{l}$. The $\mathrm{LC}_{50}$ values for $\mathrm{ABT}-737$ were estimated to be $2.24 \pm$ $0.08,1.93 \pm 0.04$, and $1.45 \pm 0.03 \mu \mathrm{mol} / \mathrm{l}$ after 24,48 and 72 hours, respectively.

In order to test effect of $\mathrm{NaBu}$ in combination with $\mathrm{ABT}$ 737 two fixed concentrations of ABT-737 (0.1 and $1 \mu \mathrm{mol} / \mathrm{l})$ were used whereas concentrations of $\mathrm{NaBu}$ were varied in complete investigated range. ABT-737 in concentration $0.1 \mu \mathrm{mol} / \mathrm{l}$ decreased relative viability of HL-60 cells to $88.8 \pm$ 5.9\% $(p>0.05), 95.8 \pm 3.3 \%(p>0.05)$ and $79.3 \pm 2.7 \%(p<$ 0.05 ) after 24,48 and 72 hours, respectively. However, we did not observe significant difference in the effect of $\mathrm{NaBu}$ on relative viability of HL- 60 cells incubated in the absence or presence of $0.1 \mu \mathrm{mol} / 1 \mathrm{ABT}-737$ (Fig. 2A, 2B and 2C). ABT737 in concentration $1 \mu \mathrm{mol} / \mathrm{l}$ decreased relative viability of HL-60 cells to $76.9 \pm 7.5 \%(p<0.05), 72.3 \pm 3.6 \%(p<$ $0.01)$ and $60.9 \pm 2.2 \%(p<0.001)$ after 24,48 and 72 hours, respectively. After 24 hours of incubation, significant difference in the effect of $\mathrm{NaBu}$ on relative viability of HL-60 cells was observed between cells incubated with $\mathrm{NaBu}$ only and cells incubated with $\mathrm{NaBu}$ in combination with $1 \mu \mathrm{mol} / 1$ ABT-737 (Fig. 2A). At this time, the relative viability of HL-60 cells in the presence of $1 \mu \mathrm{mol} / 1$ of ABT-737 was significantly decreased at concentrations of $\mathrm{NaBu} 2$ and 5 $\mathrm{mmol} / \mathrm{l}$ as compared to the relative viability of HL-60 cells incubated with $\mathrm{NaBu}$ only $(43.7 \pm 6.1 \%$ versus $87 \pm 3.9 \%$ and $36 \pm 4.6 \%$ versus $76.7 \pm 1.2 \%$, respectively). After 48 and 72
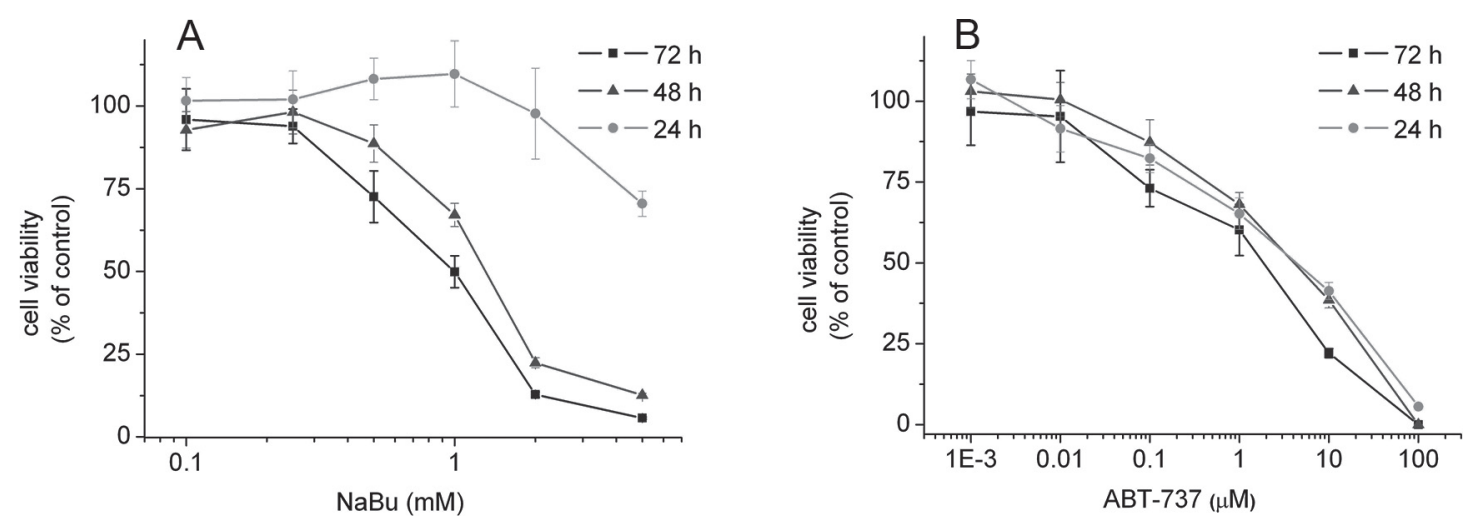

Figure 1. Effect of $\mathrm{NaBu}(\mathbf{A})$ and ABT-737 (B) on relative viability of HL-60 cells. HL-60 cells were incubated for 72 hours in the presence of various concentrations of either $\mathrm{NaBu}(0.1-5 \mathrm{mmol} / \mathrm{l})$ or ABT-737 (0.001-100 $\mu \mathrm{mol} / \mathrm{l})$ and relative cell viability was determined by the MTT assay. Representative curve of three independent experiments results from one experiment performed in triplicate. 

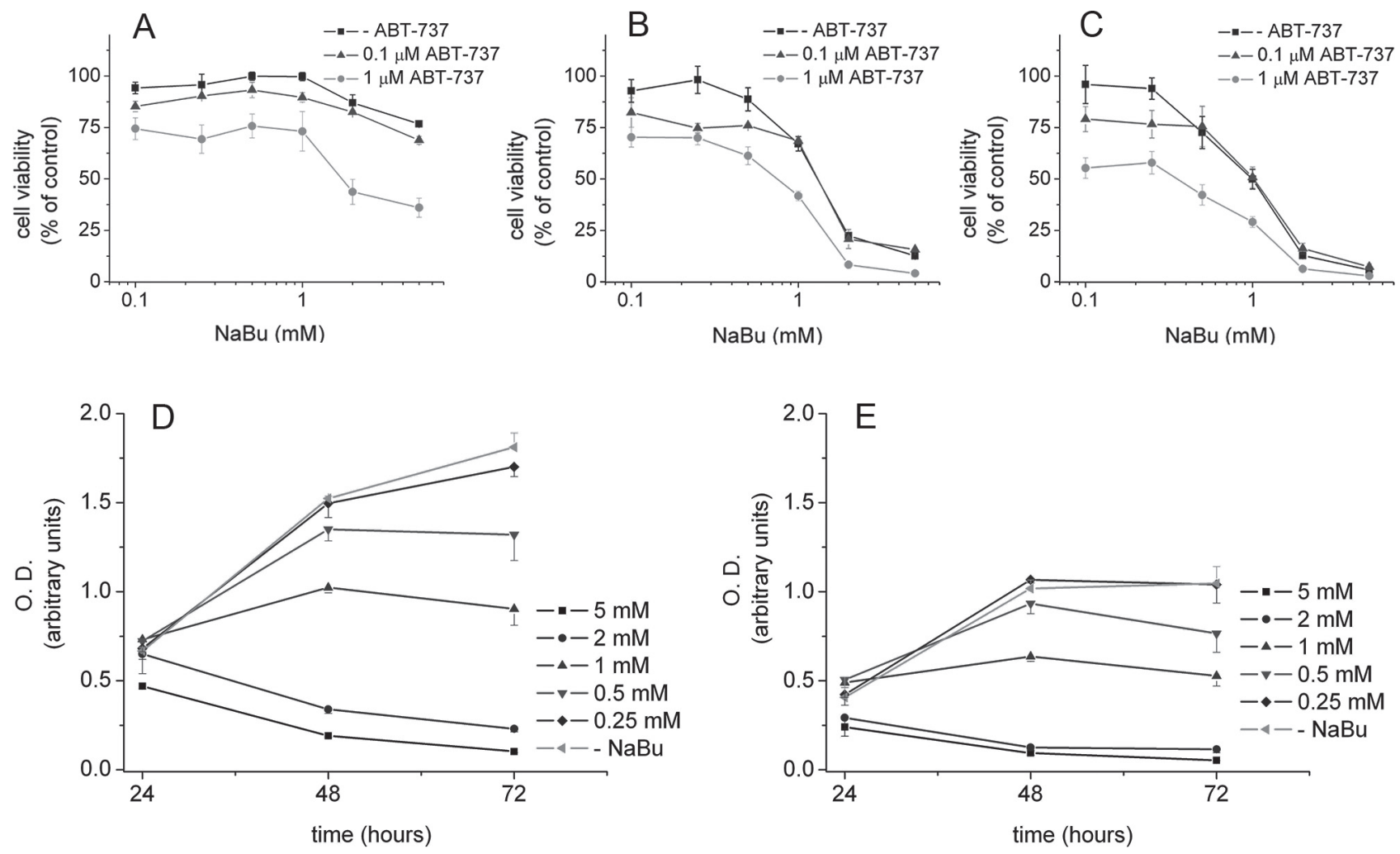

Figure 2. Effect of $\mathrm{NaBu}$ alone and in combination with of ABT-737 on relative viability of and growth of HL-60 cells. HL-60 cells were incubated for 24 (A), 48 (B) and $72(\mathbf{C})$ hours in the presence of various concentrations of $\mathrm{NaBu}(0.1-5 \mathrm{mmol} / \mathrm{l})$ alone and $\mathrm{NaBu}$ in combination with ABT-737 (either 0.1 or $1 \mu \mathrm{mol} / \mathrm{l}$ ) and relative cell viability was determined by the MTT assay. Representative curve of three independent experiments results from one experiment performed in triplicate. HL-60 cells were grown for 72 hours in the presence of various concentrations of $\mathrm{NaBu}(0.1-5 \mathrm{mmol} / \mathrm{l})$ alone $(\mathbf{D})$ and $\mathrm{NaBu}$ in combination with $1 \mu \mathrm{mol} / \mathrm{l}$ ABT-737 (E). Cell growth was determined by the MTT assay and expressed as time course of optical density (O. D.) of formazan produced by particular cell population. Representative curve of three independent experiments results from one experiment performed in triplicate.

hours (Fig. 2B and 2C), the effect of $\mathrm{NaBu}$ in the presence of $1 \mu \mathrm{mol} / 1$ of ABT-737 on relative viability HL- 60 cells was copying the effect observed when cells were incubated with

Table 1. Results of combined drug effect analysis

\begin{tabular}{cccc}
\hline \multirow{2}{*}{$\begin{array}{c}\mathrm{NaBu} \\
(\mathrm{mmol} / \mathrm{l})\end{array}$} & \multicolumn{3}{c}{ Combination index } \\
\cline { 2 - 4 } & 24 hours & 48 hours & 72 hours \\
\hline 0.1 & 4.455 & 0.802 & 2.080 \\
0.25 & 2.781 & 0.991 & 2.638 \\
0.5 & 5.467 & 0.975 & 1.439 \\
1 & 4.039 & 0.838 & 1.115 \\
2 & 0.378 & 0.316 & 0.472 \\
5 & 0.199 & 0.425 & 0.717 \\
\hline
\end{tabular}

Combined drug effect analysis was performed as described in Materials and Methods using results presented on Figures 2A, 2B and $2 \mathrm{C}$ related to combination of $1 \mu \mathrm{mol} / \mathrm{l} \mathrm{ABT}-737$ with indicated concentrations of $\mathrm{NaBu}$.
$\mathrm{NaBu}$ only. The calculated combination indexes (Table 1) indicate that at concentrations of $\mathrm{NaBu} 2$ and $5 \mathrm{mmol} / \mathrm{l}$ the effect of $\mathrm{NaBu}$ combination with $1 \mu \mathrm{mol} / \mathrm{l} \mathrm{ABT}-737$ is synergistic while $\mathrm{NaBu}$ in concentrations $1 \mathrm{mmol} / \mathrm{l}$ and less exhibit mainly antagonistic effect.

Incubation of HL-60 cells with different concentration of $\mathrm{NaBu}$ for 24, 48 and 72 hours has revealed that $\mathrm{NaBu}$ at concentration $1 \mathrm{mmol} / \mathrm{l}$ inhibits cell growth (Fig. 2D). $\mathrm{NaBu}$ in concentrations higher than $2 \mathrm{mmol} / \mathrm{l}$ induced death of HL-60 cells which was manifested by decreased optical density observed after 48 hours of incubation (Fig. 2D). Significant decrease of the cell viability was observed already after 24 hours of incubation of HL-60 cells either with $1 \mu \mathrm{mol} / \mathrm{l}$ ABT-737 or its combination with different concentrations of $\mathrm{NaBu}$ (Fig. 2E). Fast initial decrease of cell viability induced by ABT-737 alone was followed with inhibition of cell growth observed after 48 hours that culminated in cell growth arrest documented after 72 hours of incubation (Fig. 2E). The effect of $\mathrm{NaBu}$ in combination 

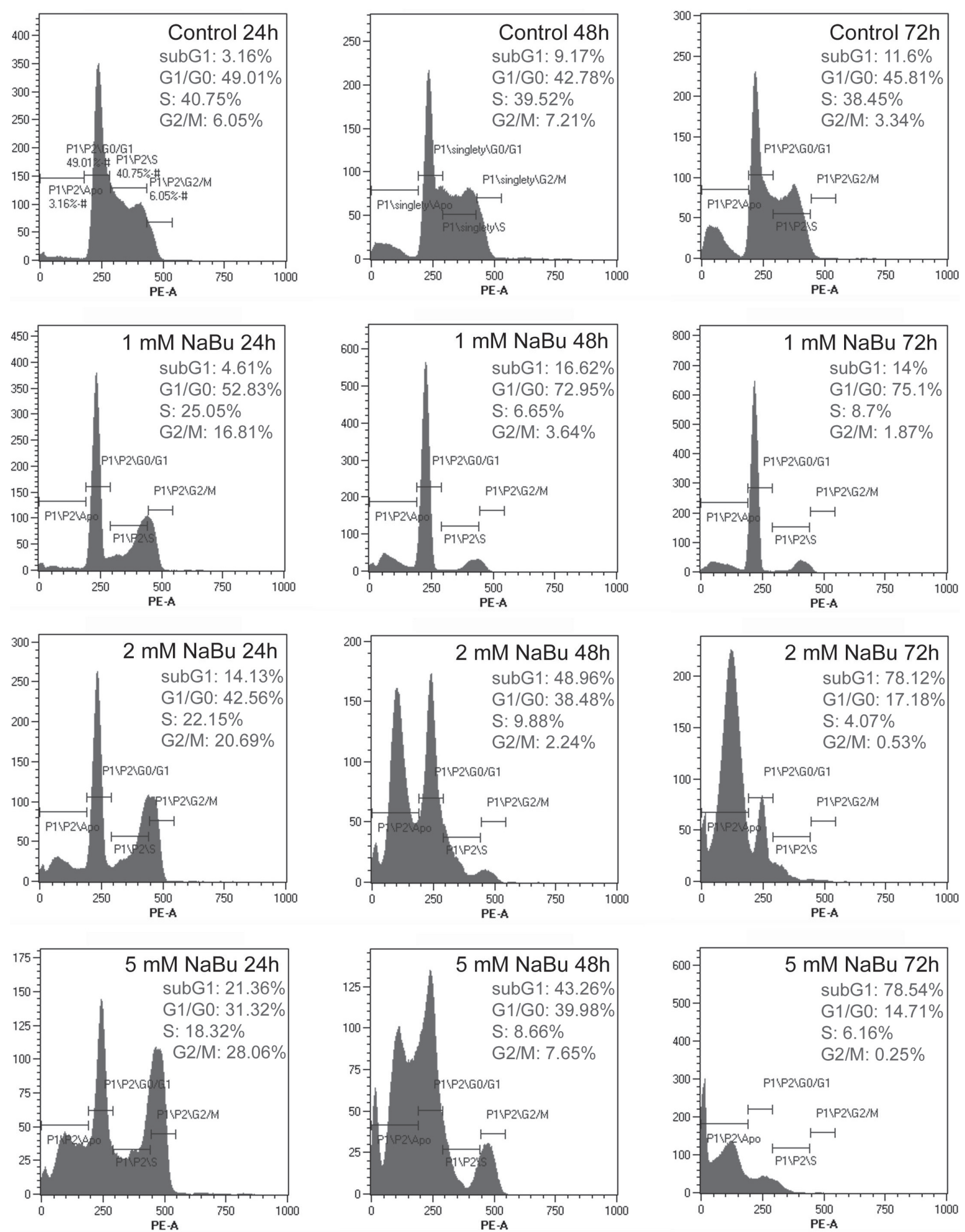

Figure 3. Effect of $\mathrm{NaBu}$ on cell cycle of HL- 60 cells. HL-60 cells were incubated for 24,48 and 72 hours in the presence of various concentrations of $\mathrm{NaBu}(1-5 \mathrm{mmol})$ and cell cycle was analysed by the propidium iodine staining. Representative curves of three independent experiments. 

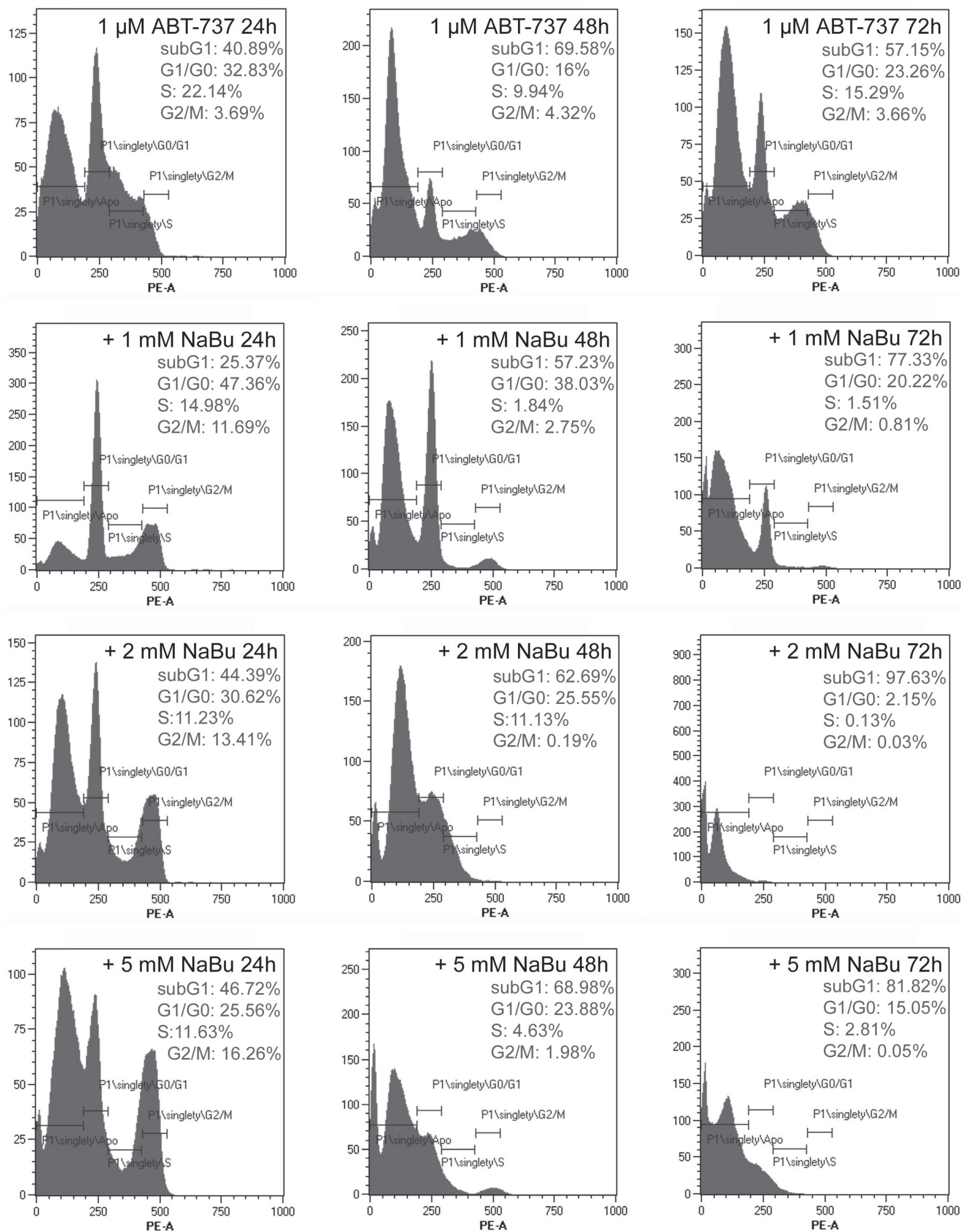

Figure 4. Effect of ABT-737 alone and in combination with NaBu on cell cycle of HL-60 cells. HL-60 cells were incubated for 24,48 and 72 hours in the presence of $1 \mu \mathrm{mol} / \mathrm{l} \mathrm{ABT-737}$ alone and $1 \mu \mathrm{mol} / \mathrm{l}$ ABT-737 in combination with various concentrations of NaBu (1-5 mmol). Cell cycle was analysed by the propidium iodine staining. Representative curves of three independent experiments. 
with $1 \mu \mathrm{mol} / \mathrm{l}$ ABT-737 was comparable to the effect of $\mathrm{NaBu}$ alone (Fig. 2E).

The study of the effect of $\mathrm{NaBu}$ and ABT-737 on the growth of HL-60 cells was paralleled with analysis of impact of $\mathrm{NaBu}$ alone and in combination with $1 \mu \mathrm{mol} / \mathrm{l} \mathrm{ABT}-737$ on cell cycle. As shown on Fig. 3, treatment of HL-60 cells with $\mathrm{NaBu}$ for 24 hours led to a concentration-dependent accumulation of G2-phase cells and decrease of S-phase and G1-phase cells, indicating block of both G1/S and G2/M cell cycle transition. After 48 and 72 hours of treatment with 1 $\mathrm{mmol} / \mathrm{l} \mathrm{NaBu}$, accumulation of G1-phase cells and lack of Sand G2-phase cells was observed (Fig. 3) indicating permanent G1-phase cell cycle arrest and commitment of G2-phase cells to cell death. $\mathrm{NaBu}$ in concentrations 2 and $5 \mathrm{mmol} / \mathrm{l}$ led to the death of HL-60 cells. The kinetic analysis revealed that first the cells in G2-phase of cell cycle are dying later followed by cells in G1-phase of cell cycle. While after 48 hours of treatment, there were still some G1-phase cells present, mainly dead cells were observed at both concentrations after 72 hours of treatment (Fig. 3). ABT-737 in concentration 1 $\mu \mathrm{mol} / \mathrm{ll}$ led to decrease of number of cells in all three stages of cell cycle and to increase of the relative amount of dead cell that was observable already after 24 hours (Fig. 4). Combination of $1 \mu \mathrm{mol} / \mathrm{l}$ of ABT-737 with $1 \mathrm{mmol} / \mathrm{l}$ of $\mathrm{NaBu}$ inhibited

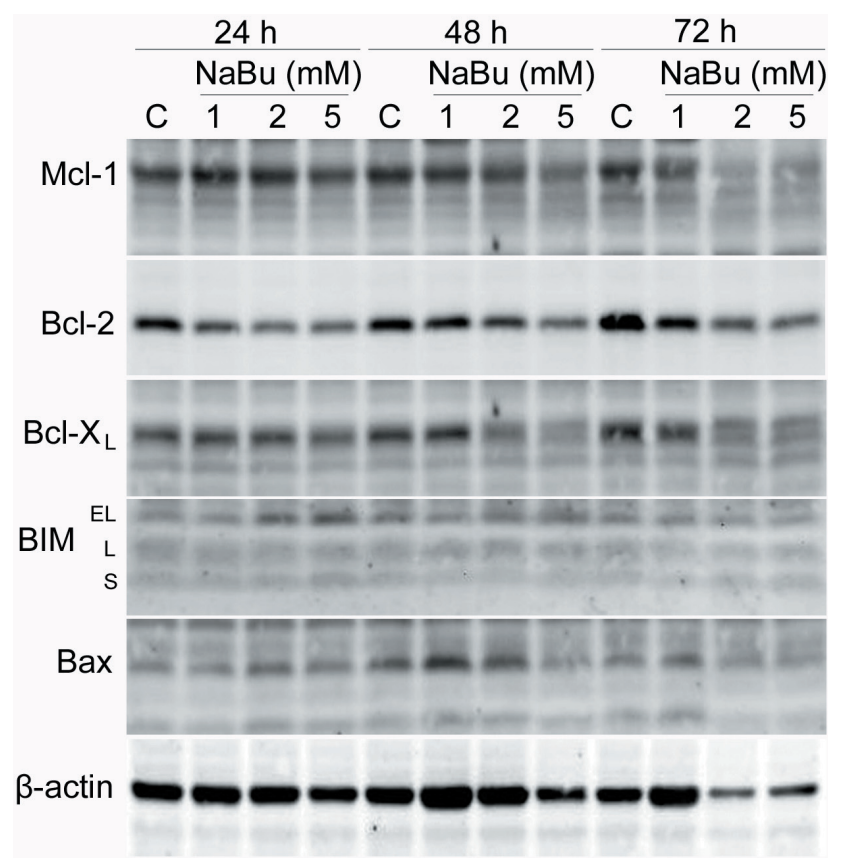

Figure 5. Effect of $\mathrm{NaBu}$ on expression of selected proteins of Bcl-2 family in HL-60 cells. Western blot analysis with the specific antibodies against selected proteins of Bcl-2 family of whole-cell extracts of HL-60 non-treated control cells (C) and cells treated with 1, 2 and $5 \mathrm{mmol} / \mathrm{l} \mathrm{NaBu}$ for 24,48 , and 72 hours. Representative Western blots of three independent experiments.

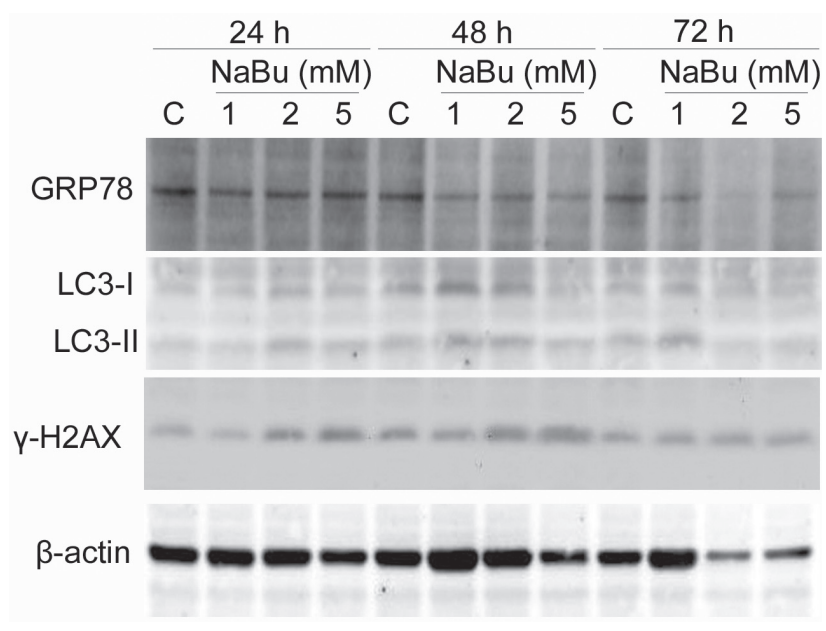

Figure 6. Effect of $\mathrm{NaBu}$ on expression of GRP78, LC3-I, LC3-II and $\gamma-\mathrm{H} 2 \mathrm{AX}$ in HL-60 cells. Western blot analysis with the specific antibodies against GRP78, LC3 $\beta$ and $\gamma$-H2AX of whole-cell extracts of HL-60 non-treated control cells (C) and cells treated with 1, 2 and $5 \mathrm{mmol} / \mathrm{l} \mathrm{NaBu}$ for 24,48 , and 72 hours. Representative Western blots of three independent experiments.

cell growth, hampered cells in G1 phase and delayed cell death induced by ABT-737 (Fig. 4). Incubation of HL-60 cells with $1 \mu \mathrm{mol} / \mathrm{l}$ of ABT-737 in combination with 2 and 5 $\mathrm{mmol} / \mathrm{l}$ of $\mathrm{NaBu}$ was associated with massive cell death that was observable already after 24 hours (Fig. 4).

In order to explain accelerated cell death induced by combination of ABT-737 and $\mathrm{NaBu}$, Western blot analysis of the effect of $\mathrm{NaBu}$ on selected proteins of Bcl-2 family was performed in time- and concentration-dependent manner. We have focused our interest on $\mathrm{Bcl}-2$ and $\mathrm{Bcl}-\mathrm{X}_{\mathrm{L}}$ that are targets of ABT-737, Mcl-1 that might be responsible for resistance of cells to ABT-737 and BIM that might be responsible for synergistic effect of ABT-737 in combination with HDACi. As shown on Figure 5, incubation of HL-60 cells with $\mathrm{NaBu}$ in concentrations 2 and $5 \mathrm{mmol} / \mathrm{l}$ was associated with increase of extra-long isoform of BIM (BIM $\left.\mathrm{BL}_{\mathrm{EL}}\right)$ level that was observed only after 24 hours as well as decrease of anti-apoptotic proteins of Bcl-2 family (Bcl-2, Bcl- $\mathrm{X}_{\mathrm{L}}$ and $\left.\mathrm{Mcl}-1\right)$. However, the effect of $\mathrm{NaBu}$ on the level of anti-apoptotic proteins of Bcl-2 family was dominant after 48 hour of incubation. Finally, $\mathrm{NaBu}$ did not affect level of Bax protein (Fig. 5).

Since Bcl-2 family proteins might be involved in endoplasmic reticulum (ER) stress signalling that can be associated either with autophagy or unfolded protein response (UPR) (Rodriguez et al. 2011), we have focused our interest on proteins that are characteristic for both processes. After 48 hours, incubation of HL-60 cells with 1,2 and $5 \mathrm{mmol} / \mathrm{l}$ of $\mathrm{NaBu}$ was associated with decreased level of master regulator of UPR, GRP78 (Fig. 6). In addition, increased level of LC3-II as a marker of autophagy (Kabeya et al. 2000) was observed after 


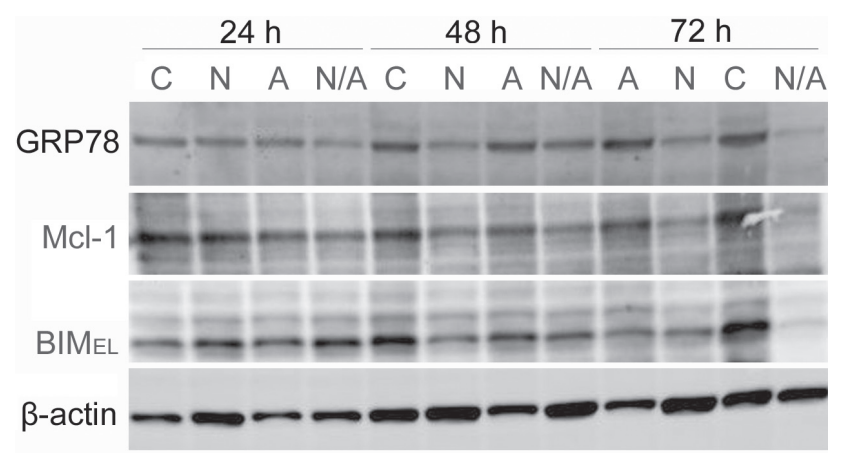

Figure 7. Effect of ABT-737 and ABT-737 in combination with $\mathrm{NaBu}$ on expression of GRP78, Mcl-1 and $\mathrm{BIM}_{\mathrm{EL}}$ in HL-60 cells. Western blot analysis with the specific antibodies against GRP78, Mcl- 1 and BIM $\mathrm{EL}_{\mathrm{EL}}$ of whole-cell extracts of HL-60 non-treated control cells (C) and cells treated with $2 \mathrm{mmol} / \mathrm{l} \mathrm{NaBu}(\mathrm{N}), 1 \mu \mathrm{mol} / \mathrm{l}$ ABT-737 (A) and with combination of $2 \mathrm{mmol} / \mathrm{l} \mathrm{NaBu}$ and $1 \mu \mathrm{mol} / \mathrm{l}$ ABT-737 (N/A) for 24, 48, and 72 hours. Representative Western blots of three independent experiments.

48 hour of incubation of HL-60 cells with $5 \mathrm{mmol} / \mathrm{l}$ of $\mathrm{NaBu}$. Finally, level of phosphorylated histone $\mathrm{H} 2 \mathrm{AX}(\gamma-\mathrm{H} 2 \mathrm{AX})$ as a marker of DNA damage (Lukas et al. 2011) was analysed. Increased level of $\gamma$-H2AX was already observed after 24 hours of cell treatment with 2 and $5 \mathrm{mmol} / \mathrm{l}$ of $\mathrm{NaBu}$ (Fig. 6).

Finally, Western blot analysis of the effect of ABT-737 and ABT-737 in combination with $\mathrm{NaBu}$ on selected proteins of Bcl-2 family was performed. We have focused our interest on Mcl-1 that might be responsible for resistance of cells to ABT-737 and BIM $\mathrm{EL}_{\mathrm{L}}$ that might be responsible for synergistic effect of ABT-737 in combination with HDACi. The effect of ABT-737 and ABT-737 in combination with $\mathrm{NaBu}$ on the level of GRP78 was also investigated. As shown on Figure 7, incubation of HL- 60 cells with $2 \mathrm{mmol} / \mathrm{l}$ of $\mathrm{NaBu}$ alone and $2 \mathrm{mmol} / \mathrm{l}$ $\mathrm{NaBu}$ in combination with $1 \mu \mathrm{mol} / \mathrm{l} \mathrm{ABT}-737$ was associated with increase of BIM $\mathrm{EL}_{\mathrm{L}}$ level that was observed only after 24 hours. The level of Mcl-1 was decreased after 48 and 72 hours of incubation of HL-60 cells with $2 \mathrm{mmol} / \mathrm{l}$ of $\mathrm{NaBu}$ alone and $2 \mathrm{mmol} / \mathrm{l} \mathrm{NaBu}$ in combination with $1 \mu \mathrm{mol} / \mathrm{l} \mathrm{ABT-737.}$ Interestingly, decreased level of GRP-78 was already observed after 24 hours of incubation of HL-60 cells with combination of $2 \mathrm{mmol} / \mathrm{l} \mathrm{NaBu}$ and $1 \mu \mathrm{mol} / \mathrm{l} \mathrm{ABT}-737$. Decreased levels of GRP-78 were observed after longer incubations of HL-60 cell (for 48 and 72 hours) with both $2 \mathrm{mmol} / \mathrm{l}$ of $\mathrm{NaBu}$ alone and 2 $\mathrm{mmol} / \mathrm{l} \mathrm{NaBu}$ in combination with $1 \mu \mathrm{mol} / \mathrm{l} \mathrm{ABT-737.ABT-737}$ alone did not exhibit impact on any of investigated proteins.

\section{Discussion}

The main finding of the presented study is that ABT-737 accelerates $\mathrm{NaBu}$-induced death of cells of leukaemic cell line
HL-60. The effect of combination of both drugs on survival of HL-60 cells seems to be synergistic at high concentrations of $\mathrm{NaBu}$ ( 2 and $5 \mathrm{mmol} / \mathrm{l}$ ) while it is rather antagonistic at concentrations of $\mathrm{NaBu}$ less than $1 \mathrm{mmol} / \mathrm{l}$. Our study has also revealed for the first time that incubation of HL- 60 cells with $\mathrm{NaBu}$ is associated with decreased level of GRP78, in addition to decrease of Bcl-2, Bcl- $\mathrm{X}_{\mathrm{L}}$ and $\mathrm{Mcl}-1$.

Our experiments have shown that both $\mathrm{NaBu}$ and ABT-737 at certain concentrations are inducing death of HL-60 cells, however, with significantly different kinetics. While ABT-737-induced cell death is fast, NaBu-induced cell death is rather slow and significant decrease of cell viability was observed after 48 hours of incubation. Fast kinetics of ABT-737-induced cell death is result of the ability of ABT-737 of direct binding to anti-apoptotic proteins of $\mathrm{Bcl}-2$ family followed with consequent initiation and execution of mitochondrial apoptosis (Oltersdorf et al. 2005). It has been documented that ABT-737 induces mitochondrial apoptosis within 2 hours and apoptosis was completely inhibited in cells deficient for Bax/Bak or caspase 9 (Vogler et al. 2009). On the other hand, the slow kinetics of $\mathrm{NaBu}$-induced death of HL-60 cells might be attributed to the fact that cell death is preceded by cell cycle arrest in G2 phase. This is evidenced by accumulation of G2-phase cells and consequent disappearance of these cells observed after 24 and 48 hours of incubation with $\mathrm{NaBu}$, respectively. Disappearance of S-phase cells observed after 24 hours of incubation indicates that $\mathrm{NaBu}$ blocks also G1/S transition what is in hand with involvement of HDACs group I and II in G1-to-S progression (Yamaguchi et al. 2010). However, accumulation of G1-phase cells observed mainly after 48 hours of incubation with $1 \mathrm{mmol} / \mathrm{l}$ of $\mathrm{NaBu}$ indicates that G1 phase arrest is followed with cell death only at higher concentrations of $\mathrm{NaBu}$. The effect of $\mathrm{NaBu}$ as well as other HDACi on cell growth and cell cycle arrest was documented using different cancer cell lines including leukaemic. It has been documented earlier that butyrate can induce cell cycle arrest in G1 phase by increasing the expression of p $21^{\text {WAF/CIP1 }}$ (Rosato et al. 2002) and p2 $7^{\text {Kip } 1}$ (Litvak et al. 1998) as well as by induction of Rb protein hypophosphorylation (Vaziri et al. 1998). HDACi can also mediate arrest of G2/M transition by activating a G2-phase checkpoint, although this is a much rarer event than HDACi-induced G1 arrest (Qiu et al. 2000; Burgess et al. 2001). The loss of the G2-phase checkpoint can determine sensitivity of cells to HDACi-induced apoptosis. The cells that retain a functional G2-phase checkpoint are resistant to the HDACi. After treatment with HDACi, the most of tumour cells that have a defective G2-phase checkpoint can initially accumulate in the G2 phase of the cell cycle, then move through this defective checkpoint and undergo apoptosis (Ruefli et al. 2001; Peart et al. 2003; Strait et al. 2005). This was also observed in our study since accumulation of G2-phase 
cells documented after 24 hours of incubation with 2 and $5 \mathrm{mmol} / \mathrm{l}$ of $\mathrm{NaBu}$ was followed with disappearance of G2phase cells and accumulation of dead cells after 48 hours of incubation. Unlike HDACi-mediated G1-phase arrest, the underlying mechanisms responsible for HDACi-mediated G2-phase arrest are poorly understood (New et al. 2012). It has been proposed that induction of an HDACi-associated G2 checkpoint might be related to hyperacetylation of pericentric heterochromatin and loss of this checkpoint can result in abnormal chromosomal segregation and nuclear fragmentation (Taddei et al. 2005). In hand with this, increased level of $\gamma-\mathrm{H} 2 \mathrm{AX}$ as a marker of damage to DNA (Lukas et al. 2011) was observed in our experiments after 24 and 48 hours of treatment with 2 and $5 \mathrm{mmol} / \mathrm{l}$ of $\mathrm{NaBu}$. Disappearance of G2-phase cells observed in our study correlated with changes at the level of Bcl-2 proteins. Downregulation of anti-apoptotic proteins $\mathrm{Bcl}-2$ and $\mathrm{Bcl}-\mathrm{X}_{\mathrm{L}}$ as well as activation of both caspase 9 and caspase 3 (Shao et al. 2004; Vrba et al. 2010) after incubation of cells with $\mathrm{NaBu}$ were observed in previous studies. In our study, we have documented decreased expression of antiapoptotic proteins Mcl-1, Bcl-2 and Bcl- $\mathrm{X}_{\mathrm{L}}$ that was dominant after 48 hours of incubation. The decreased expression of antiapoptotic proteins of Bcl-2 family is associated with mitochondrial apoptosis initiation as it was documented by different experimental protocols aimed to find new treatment of acute leukaemia (Jurečeková et al. 2011). Previous studies have also documented that G2-phase arrest can be associated with consequent initiation of mitochondrial apoptosis (Strait et al. 2005; Xiao et al. 2007; Dai et al. 2011).

Up-regulation of pro-apoptotic proteins of Bcl-2 family represents another mechanism of mitochondrial apoptosis initiation. HDACi-induced up-regulation of BIM (Kuroda et al. 2006; Zhang et al. 2008) has been considered to be responsible for synergistic interaction between HDACi and ABT-737. In our experiments, increased level of BIM $\mathrm{EL}_{\mathrm{L}}$ has been observed after 24 hours of incubation of HL-60 cells with 2 and $5 \mathrm{mmol} / \mathrm{l}$ of $\mathrm{NaBu}$. It seems that this up-regulation does not have significant impact on cell viability observed after 24 hours of incubation of HL-60 cells with $2 \mathrm{mmol} / \mathrm{l}$ of $\mathrm{NaBu}$ only. However, the up-regulation of BIM $\mathrm{EL}_{\mathrm{L}}$ correlated well with significantly decreased viability of HL-60 cells observed after 24 hour when 2 and $5 \mathrm{mmol} / \mathrm{l}$ of $\mathrm{NaBu}$ was combined with $1 \mu \mathrm{mol} / \mathrm{l}$ of ABT. Thus acceleration of cell death induction observed after incubation of HL-60 cells with combination of ABT-737 and $\mathrm{NaBu}$ might be attributable to the changes in $\mathrm{BIM}_{\mathrm{EL}}$ level and more efficient killing of HL-60 cells with ABT-737. In addition, acceleration of death of HL-60 cells is most probably result of direct binding of ABT-737 to anti-apoptotic proteins of $\mathrm{Bcl}-2$ family that exhibits faster kinetics than decrease of levels of Bcl-2 proteins observed after 48 hours incubation of cells with $\mathrm{NaBu}$ only.
Several members of Bcl-2 family also regulate physiological processes at the ER through dynamic interactions with different targets (Rodriguez et al. 2011). Therefore, changes in equilibrium between pro- and anti-apoptotic proteins of Bcl-2 family might be associated with ER stress signalling. Adaptation of cells to ER stress depends on the activation of unfolded protein response (UPR) or protein degradation pathways such as autophagy (Rodriguez et al. 2011; Gorman et al. 2012). Under chronic or irreversible ER stress, cells undergo apoptosis, where the $\mathrm{Bcl}-2$ protein family plays a crucial role at the mitochondria to trigger cytochrome c release and formation of apoptosome (Rodriguez et al. 2011). The ability of ABT-737 (Malik et al. 2011) as well as HDACi (Shao et al. 2004; Tang et al. 2011) to induce autophagy has already been documented. Our results could be in favour of inducing autophagy by $\mathrm{NaBu}$. However, changes at the level of LC3-II that is considered as molecular marker of autophagy induction (Kabeya et al. 2000) were observed only after 48 hours of incubation of HL-60 cells with $5 \mathrm{mmol} / \mathrm{l}$ of $\mathrm{NaBu}$. Induction of ER stress signalling by ABT-737 through up-regulation of GRP78 expression (Risberg et al. 2011) as well as by class I HDACi associated with acetylation of GRP78 (Kahali et al. 2012) has been documented recently. GRP78 master regulator of ER stress signalling that is not member of $\mathrm{Bcl}-2$ family proteins exhibits multiple anti-apoptotic properties (Reddy et al. 2003) and plays an important role in solid tumour progression and oncogenesis (Luo and Lee 2013). The function of GRP78 in the hematopoietic system is just emerging, however, recent study clearly revealed involvement of GRP78 in hematopoietic stem cell survival and lymphogenesis (Wey et al. 2012a). In addition, it has been shown that GRP78 expression is up-regulated in various forms of human leukaemia and implicated as causative factor for therapeutic resistance and early relapse (Tanimura et al. 2009; Rosati et al. 2010; Uckun et al. 2011; Wey et al. 2012b). In our experiments, we have detected GRP78 to be expressed in non-treated HL60 cells and treatment of the cells with $\mathrm{NaBu}$ for 48 hours was associated with decrease of GRP78 level. In addition decreased level of GRP78 was documented after 24 hours of cell treatment with combination of ABT-737 and NaBu. Considering anti-apoptotic functions of GRP78, decrease of GRP78 observed after 48 hours of incubation of cells with $\mathrm{NaBu}$ might represent mechanism of $\mathrm{NaBu}$-induced apoptosis initiation independent from that associated with changes in Bcl-2 protein levels or functions. Finally, decreased level of GRP78 after 24 hours of incubation of HL-60 cells with combination of $\mathrm{NaBu}$ and ABT-737 might represent another mechanism of acceleration of HL-60 cell death.

In conclusion, we have documented in this study that ABT-737 accelerates NaBu-induced death of HL-60 cells most probably due to common cell death mechanism that is mitochondrial apoptosis as well as due to accelerated de- 
crease of GRP78 observed after the treatment of cells with combination of $\mathrm{NaBu}$ and ABT-737. The effect of combination of both drugs on survival of HL-60 cells seems to be synergistic at high concentrations of $\mathrm{NaBu}(2$ and $5 \mathrm{mmol} /$ ) while it is rather antagonistic at concentrations of $\mathrm{NaBu}$ less than $1 \mathrm{mmol} / \mathrm{l}$. Synergistic effect of $\mathrm{NaBu}$ and ABT737 might be explained by the ability of $\mathrm{NaBu}$ to increase level of BIM $\mathrm{EL}_{\mathrm{EL}}$ as well as by the impact of combination of $\mathrm{NaBu}$ and ABT-737 on the level of GRP78. The antagonistic effect of $\mathrm{NaBu}$ and ABT-737 might be probably attributed to the ability of low concentrations of $\mathrm{NaBu}$ to induce differentiation and thus to possible decrease of sensitivity of HL-60 to ABT-737. Finally, it might be assumed that $\mathrm{NaBu}$ is capable to induce cell death with mechanisms independent from mitochondrial apoptosis. In favour of this, our study has revealed that incubation of HL-60 cells with $\mathrm{NaBu}$ is also associated with decreased level of GRP78 that acts at the level of ER stress signalling and exhibits anti-apoptotic functions.

Acknowledgments. This work was supported by project „Support of human resources development using the most modern methods and forms of education on JFM KU in Martin" co-financed from European Union sources and European Social Fund.

\section{References}

Abrams S. L., Steelman L. S., Shelton J. G., Chappell W., Basecke J., Stivala F., Donia M., Nicoletti F., Libra M., Martelli A. M., McCubrey J. A. (2010): Enhancing therapeutic efficacy by targeting non-oncogene addicted cells with combinations of signal transduction inhibitors and chemotherapy. Cell Cycle 9, 1839-1846 http://dx.doi.org/10.4161/cc.9.9.11544

Bolden J. E., Peart M. J., Johnstone R. W. (2006): Anticancer activities of histone deacetylase inhibitors. Nat. Rev. Drug Discov. 5, 769-784 http://dx.doi.org/10.1038/nrd2133

Burgess A. J., Pavey S., Warrener R., Hunter L. J., Piva T. J., Musgrove E. A., Saunders N., Parsons P. G., Gabrielli B. G. (2001): Up-regulation of p21(WAF1/CIP1) by histone deacetylase inhibitors reduces their cytotoxicity. Mol. Pharmacol. 60, 828-837

Calabresse C., Venturini L., Ronco G., Villa P., Chomienne C., Belpomme D. (1993): Butyric acid and its monosaccharide ester induce apoptosis in the HL-60 cell line. Biochem. Biophys. Res. Commun. 195, 31-38 http://dx.doi.org/10.1006/bbrc.1993.2005

Carew J. S., Giles F. J., Nawrocki S. T. (2008): Histone deacetylase inhibitors: mechanisms of cell death and promise in combination cancer therapy. Cancer Lett. 269, 7-17 http://dx.doi.org/10.1016/j.canlet.2008.03.037

Chauhan D., Velankar M., Brahmandam M., Hideshima T., Podar K., Richardson P., Schlossman R., Ghobrial I., Raje N., Munshi N., Anderson K. C. (2007): A novel Bcl-2/Bcl-X(L)/Bcl-w inhibitor ABT-737 as therapy in multiple myeloma. Oncogene 26, 2374-2380

http://dx.doi.org/10.1038/sj.onc.1210028

Chen S., Dai Y., Harada H., Dent P., Grant S. (2007): Mcl-1 downregulation potentiates ABT-737 lethality by cooperatively inducing Bak activation and Bax translocation. Cancer Res. 67, 782-791

http://dx.doi.org/10.1158/0008-5472.CAN-06-3964

Chen S., Dai Y., Pei X. Y., Grant S. (2009): Bim upregulation by histone deacetylases inhibitors mediates interactions with the Bcl-2 antagonist ABT-737: evidence for distinct roles for Bcl-2, Bcl-xl, and Mcl-1. Mol. Cell Biol. 29, 6149-669 http://dx.doi.org/10.1128/MCB.01481-08

Dai Q. S., Liu W., Wang X. B., Lu N., Gong D. D., Kong L. Y., Guo Q. L. (2011): NCPMF-60 induces G2/M cell cycle arrest and apoptosis in human hepatocellular carcinoma HepG2 cells. Anticancer Drugs 22, 46-57 http://dx.doi.org/10.1097/CAD.0b013e3283405801

Del Gazo Moore V., Brown J. R., Certo M., Love T. M., Novina C. D., Letai A. (2007): Chronic lymphocytic leukemia requires BCL2 to sequester prodeath BIM, explaining sensitivity to BCL2 antagonist ABT-737. J. Clin. Investig. 117, 112-121 http://dx.doi.org/10.1172/JCI28281

Deng J., Carlson N., Takeyama K., Dal Cin P., Shipp M., Letai A. (2007): BH3 profiling identifies three distinct classes of apoptotic blocks to predict response to ABT-737 and conventional chemotherapeutic agents. Cancer Cell. 12, 171-185 http://dx.doi.org/10.1016/j.ccr.2007.07.001

Gorman A. M., Healy S. J., Jäger R., Samali A. (2012): Stress management at the ER: regulators of ER stress-induced apoptosis. Pharmacol Ther. 134, 306-316 http://dx.doi.org/10.1016/j.pharmthera.2012.02.003

Fauser J. K., Prisciandaro L. D., Cummins A. G., Howarth G. S. (2011): Fatty acids as potential adjunctive colorectal chemotherapeutic agents. Cancer Biol. Ther. 11, 724-731 http://dx.doi.org/10.4161/cbt.11.8.15281

Filippovich I., Sorokina N., Khanna K. K., Lavin M. F. (1994): Butyrate induced apoptosis in lymphoid cells preceded by transient over-expression of HSP70 mRNA. Biochem. Biophys. Res. Commun. 198, 257-265 http://dx.doi.org/10.1006/bbrc.1994.1036

Jurečeková J., Hatok J., Štefániková A., Dobrota D., Račay P. (2011): Targeting of Bcl-2 family proteins for treatment of acute leukaemia. Gen. Physiol. Biophys. 30, S3-12 http://dx.doi.org/10.4149/gpb_2011_SI1_3

Kabeya Y., Mizushima N., Ueno T., Yamamoto A., Kirisako T., Noda T., Kominami E., Ohsumi Y., Yoshimori T. (2000): LC3, a mammalian homologue of yeast Apg8p, is localized in autophagosome membranes after processing. EMBO J. 19, $5720-5728$ http://dx.doi.org/10.1093/emboj/19.21.5720

Kahali S., Sarcar B., Prabhu A., Seto E., Chinnaiyan P. (2012): Class I histone deacetylases localize to the endoplasmic reticulum and modulate the unfolded protein response. FASEB J. 26, $2437-2445$ http://dx.doi.org/10.1096/f.11-193706

Konopleva M., Contractor R., Tsao T., Samudio I., Ruvolo P. P., Kitada S., Deng X., Zhai D., Shi X. Y., Sneed T., et al. (2006): 
Mechanisms of apoptosis sensitivity and resistance to the $\mathrm{BH} 3$ mimetic ABT-737 in acute myeloid leukemia. Cancer Cell 10, 375-388 http://dx.doi.org/10.1016/j.ccr.2006.10.006

Kuroda J., Puthalakath H., Cragg M. S., Kelly P. N., Bouillet P., Huang D. C., Kimura S., Ottmann O. G., Druker B. J., Villunger A., Roberts A. W., Strasser A. (2006): Bim and Bad mediate imatinib-induced killing of $\mathrm{Bcr} / \mathrm{Abl}$ leukemic cells, and resistance due to their loss is overcome by a $\mathrm{BH} 3$ mimetic. Proc. Natl. Acad. Sci. USA 103, 14907-14912 http://dx.doi.org/10.1073/pnas.0606176103

Lin X., Morgan-Lappe S., Huang X., Li L., Zakula D. M., Vernetti L. A., Fesik S. W., Shen Y. (2007): ,Seed' analysis of off-target siRNAs reveals an essential role of Mcl-1 in resistance to the small-molecule Bcl-2/Bcl-xl inhibitor ABT-737. Oncogene 26, 3972-3979

http://dx.doi.org/10.1038/sj.onc.1210166

Litvak D. A., Evers B. M., Hwang K. O., Hellmich M. R., Ko T. C., Townsend C. M. Jr. (1998): Butyrate-induced differentiation of Caco-2 cells is associated with apoptosis and early induction of p21Waf1/Cip1 and p27Kip1. Surgery 124, 161-199 http://dx.doi.org/10.1016/S0039-6060(98)70116-3

Lukas J., Lukas C., Bartek J. (2011): More than just a focus: The chromatin response to DNA damage and its role in genome integrity maintenance. Nat. Cell Biol. 13, 1161-1169 http://dx.doi.org/10.1038/ncb2344

Luo B., Lee A. S. (2013): The critical roles of endoplasmic reticulum chaperones and unfolded protein response in tumorigenesis and anticancer therapies. Oncogene 32, 805-818 http://dx.doi.org/10.1038/onc.2012.130

Malik S. A., Orhon I., Morselli E., Criollo A., Shen S., Mari-o G., BenYounes A., Bénit P., Rustin P., Maiuri M. C., Kroemer G. (2011): BH3 mimetics activate multiple pro-autophagic pathways. Oncogene 30, 3918-3929

http://dx.doi.org/10.1038/onc.2011.104

Marks P. A. (2010): Histone deacetylase inhibitors: a chemical genetics approach to understanding cellular functions. Biochim. Biophys. Acta 1799, 717-725 http://dx.doi.org/10.1016/j.bbagrm.2010.05.008

New M., Olzscha H., La Thangue N. B. (2012): HDAC inhibitor-based therapies: can we interpret the code? Mol. Oncol. 6, 637-656 http://dx.doi.org/10.1016/j.molonc.2012.09.003

Oltersdorf T., Elmore S. W., Shoemaker A. R., Armstrong R. C., Augeri D. J., Belli B. A., Bruncko M., Deckwerth T. L., Dinges J., Hajduk P. J., et al. (2005): An inhibitor of Bcl-2 family proteins induces regression of solid tumours. Nature 435, 677-681 http://dx.doi.org/10.1038/nature03579

Pajak B., Orzechowski A., Gajkowska B. (2007): Molecular basis of sodium butyrate-dependent proapoptotic activity in cancer cells. Adv. Med. Sci. 52, 83-88

Peart M. J., Tainton K. M., Ruefli A. A., Dear A. E., Sedelies K. A., O'Reilly L. A., Waterhouse N. J., Trapani J. A., Johnstone R. W. (2003): Novel mechanisms of apoptosis induced by histone deacetylase. Cancer Res. 63, 4460-4471

Qiu L., Burgess A., Fairlie D. P., Leonard H., Parsons P. G., Gabrielli B. G. (2000): Histone deacetylase inhibitors trigger a G2 checkpoint in normal cells that is defective in tumor cells. Mol. Biol. Cell 11, 2069-2083 http://dx.doi.org/10.1091/mbc.11.6.2069

Reddy R. K., Mao C., Baumeister P., Austin R. C., Kaufman R. J., Lee A. S. (2003): Endoplasmic reticulum chaperone protein GRP78 protects cells from apoptosis induced by topoisomerase inhibitors: role of ATP binding site in suppression of caspase-7 activation. J. Biol. Chem. 278, 20915-20924 http://dx.doi.org/10.1074/jbc.M212328200

Risberg K., Fodstad Ø., Andersson Y. (2011): Synergistic anticancer effects of the 9.2.27PE immunotoxin and ABT-737 in melanoma. PLoS One 6, e24012 http://dx.doi.org/10.1371/journal.pone.0024012

Rodriguez D., Rojas-Rivera D., Hetz C. (2011): Integrating stress signals at the endoplasmic reticulum: The BCL-2 protein family rheostat. Biochim. Biophys. Acta 1813, 564-574 http://dx.doi.org/10.1016/j.bbamcr.2010.11.012

Rosati E., Sabatini R., Rampino G., De Falco F., Di Ianni M., Falzetti F., Fettucciari K., Bartoli A., Screpanti I., Marconi P. (2010): Novel targets for endoplasmic reticulum stress-induced apoptosis in B-CLL. Blood 116, 2713-2723 http://dx.doi.org/10.1182/blood-2010-03-275628

Rosato R. R., Almenara J. A., Cartee L., Betts V., Chellappan S. P., Grant S. (2002): The cyclin-dependent kinase inhibitor flavopiridol disrupts sodium butyrate-induced p21WAF1/ CIP1 expression and maturation while reciprocally potentiating apoptosis in human leukemia cells. Mol. Cancer Ther. 1, 253-266

Rosato R. R., Almenara J. A., Dai Y., Grant S. (2003): Simultaneous activation of the intrinsic and extrinsic pathways by histone deacetylase (HDAC) inhibitors and tumor necrosis factor-related apoptosis-inducing ligand (TRAIL) synergistically induces mitochondrial damage and apoptosis in human leukemia cells. Mol. Cancer Ther. 2, 1273-1284

Ruefli A. A., Ausserlechner M. J., Bernhard D., Sutton V. R., Tainton K. M., Kofler R., Smyth M. J., Johnstone R. W. (2001): The histone deacetylase inhibitor and chemotherapeutic agent suberoylanilide hydroxamic acid (SAHA) induces a cell-death pathway characterized by cleavage of Bid and production of reactive oxygen species. Proc. Natl. Acad. Sci. USA 98, 10833-10838 http://dx.doi.org/10.1073/pnas.191208598

Shao Y., Gao Z, Marks P. A., Jiang X. (2004): Apoptotic and autophagic cell death induced by histone deacetylase inhibitors. Proc. Natl. Acad. Sci. USA 101, 18030-18035 http://dx.doi.org/10.1073/pnas.0408345102

Song J. H., Kandasamy K., Zemskova M., Lin Y. W., Kraft A. S. (2011): The BH3 mimetic ABT-737 induces cancer cell senescence. Cancer Res. 71, 506-515 http://dx.doi.org/10.1158/0008-5472.CAN-10-1977

Strait K. A., Warnick C. T., Ford C. D., Dabbas B., Hammond E. H., Ilstrup S. J. (2005): Histone deacetylase inhibitors induce G2-checkpoint arrest and apoptosis in cisplatinum-resistant ovarian cancer cells associated with overexpression of the Bcl2-related protein Bad. Mol Cancer Ther. 4, 603-611 http://dx.doi.org/10.1158/1535-7163.MCT-04-0107

Taddei A., Roche D., Bickmore W. A. Almouzni G. (2005): The effects of histone deacetylase inhibitors on heterochroma- 
tin: implications for anticancer therapy? EMBO Rep. 6, $520-524$ http://dx.doi.org/10.1038/sj.embor.7400441

Tang Y., Chen Y., Jiang H., Nie D. (2011): Short-chain fatty acids induced autophagy serves as an adaptive strategy for retarding mitochondria-mediated apoptotic cell death. Cell Death Differ. 18, 602-618 http://dx.doi.org/10.1038/cdd.2010.117

Tanimura A., Yujiri T., Tanaka Y., Hatanaka M., Mitani N., Nakamura Y., Mori K., Tanizawa Y. (2009): The anti-apoptotic role of the unfolded protein response in Bcr-Abl-positive leukemia cells. Leuk. Res. 33, 924-928 http://dx.doi.org/10.1016/j.leukres.2009.01.027

Uckun F. M., Qazi S., Ozer Z., Garner A. L., Pitt J., Ma H., Janda K. D. (2011): Inducing apoptosis in chemotherapy-resistant B-lineage acute lymphoblastic leukaemia cells by targeting HSPA5, a master regulator of the anti-apoptotic unfolded protein response signalling network. Br. J. Haematol. 153, 741-752 http://dx.doi.org/10.1111/j.1365-2141.2011.08671.x

van Delft M. F., Wei A. H., Mason K. D., Vandenberg C. J., Chen L., Czabotar P. E., Willis S. N., Scott C. L., Day C. L., Cory S., Adams J. M., Roberts A. W., Huang D. C. (2006): The BH3 mimetic ABT-737 targets selective Bcl-2 proteins and efficiently induces apoptosis via Bak/Bax if Mcl-1 is neutralized. Cancer Cell 10, 389-399 http://dx.doi.org/10.1016/j.ccr.2006.08.027

Vaziri C., Stice L., Faller D. V. (1998): Butyrate-induced G1 arrest results from p21-independent disruption of retinoblastoma protein-mediated signals. Cell Growth Differ. 9, 465-474

Vogler M., Weber K., Dinsdale D., Schmitz I., Schulze-Osthoff K., Dyer M. J., Cohen G. M. (2009): Different forms of cell death induced by putative BCL2 inhibitors. Cell Death Differ. 16, 1030-1039 http://dx.doi.org/10.1038/cdd.2009.48

Vrba J., Dolezel P., Ulrichova J. (2010): Neutrophilic differentiation modulates the apoptotic response of HL-60 cells to sodium butyrate and sodium valproate. Neoplasma 57, 438-448 http://dx.doi.org/10.4149/neo_2010_05_438

Wey S., Luo B., Lee A. S. (2012a): Acute Inducible Ablation of GRP78 Reveals Its Role in Hematopoietic Stem Cell Survival,
Lymphogenesis and Regulation of Stress Signaling. PLoS One 7, e39047 http://dx.doi.org/10.1371/journal.pone.0039047

Wey S., Luo B., Tseng C. C., Ni M., Zhou H., Fu Y., Bhojwani D., Carroll W. L., Lee A. S. (2012b): Inducible knockout of GRP78/BiP in the hematopoietic system suppresses Ptennull leukemogenesis and AKT oncogenic signaling. Blood 119, 817-825 http://dx.doi.org/10.1182/blood-2011-06-357384

Whitecross K. F., Alsop A. E., Cluse L. A., Wiegmans A., Banks K. M., Coomans C., Peart M. J., Newbold A., Lindemann R. K., Johnstone R. W. (2009): Defining the target specificity of ABT737 and synergistic antitumor activities in combination with histone deacetylase inhibitors. Blood 113, 1982-1991 http://dx.doi.org/10.1182/blood-2008-05-156851

Xiao Y., Yang F. Q., Li S. P., Gao J. L., Hu G., Lao S. C., Conceição E. L, Fung K. P., Wangl Y. T., Lee S. M. (2007): Furanodiene induces G2/M cell cycle arrest and apoptosis through MAPK signaling and mitochondria-caspase pathway in human hepatocellular carcinoma cells. Cancer Biol. Ther. 6, 1044-1050 http://dx.doi.org/10.4161/cbt.6.7.4317

Yamaguchi T., Cubizolles F., Zhang Y., Reichert N., Kohler H., Seiser C., Matthias P. (2010) Histone deacetylases 1 and 2 act in concert to promote the G1-to-S progression. Genes Dev. 24, 455-469 http://dx.doi.org/10.1101/gad.552310

Zhang W., Konopleva M., Ruvolo V. R., McQueen T., Evans R. L., Bornmann W. G., McCubrey J., Cortes J., Andreeff M. (2008): Sorafenib induces apoptosis of AML cells via Bim-mediated activation of the intrinsic apoptotic pathway. Leukemia 22, 808-818 http://dx.doi.org/10.1038/sj.leu.2405098

Zimra Y., Wasserman L., Maron L., Shaklai M., Nudelman A., Rephaeli A. (1997): Butyric acid and pivaloyloxymethyl butyrate, AN-9, a novel butyric acid derivative, induce apoptosis in HL-60 cells. J. Cancer Res. Clin. Oncol. 123, $152-160$

Received: March 19, 2013

Final version accepted: May 31, 2013 